\title{
MEREK DESTINASI WISATA DALAM SITUS DINAS PARIWISATA NTT: ANALISIS SEMIOTIKA PEMASARAN LAURA OSWALD
}

\author{
Silvanus Alvin \\ Dosen Ilmu Komunikasi Universitas Bunda Mulia \\ silvanusalvin@gmail.com
}

\begin{abstract}
The government of Indonesia, lead by Jokowi and Jusuf Kalla, has targeted to attract 20 million foreign tourists by 2019. East Nusa Tenggara (NTT) is one of many tourist destinations in Indonesia that possess beautiful nature scenery. The NTT Tourism Office informs its magnificent destinations through website. This research seeks to understand the brand destination of NTT that is communicated through the official website managed by The Tourism Office. The methodology in this research uses Laura Oswald's marketing semiotics. This study has shown that the brand destination of NTT are nature tourism and religious tourism. Further, tourist destinations in NTT are packaged as a place that is good for both physical and spiritual, as well as targeting tourists who live daily in urban areas. In addition, another major finding is the main target of NTT tourism is local tourist. This contrasts with the government's effort to attract foreign tourists.
\end{abstract}

\begin{abstract}
Abstrak
Pemerintahan Jokowi-JK menargetkan 20 juta wisatawan mancanegara pada 2019. Nusa Tenggara Timur (NTT) merupakan salah satu destinasi wisata di Indonesia yang memiliki potensi alam besar. Dinas Pariwisata NTT pun memasarkan destinasinya melalui website. Penelitian ini bertujuan untuk mengetahui merek destinasi NTT yang berusaha dikomunikasikan melalui situs resmi yang dikelola oleh dinas pariwisatanya. Penelitian dilaksanakan menggunakan metode semiotika pemasaran hasil pemikiran Laura Oswald. Penelitian ini menemukan bahwa merek destinasi NTT adalah wisata alam dan wisata religi. Lebih lanjut, destinasi wisata di NTT dikemas sebagai tempat yang baik bagi jasmani dan rohani, serta menyasar wisatawan yang menetap di perkotaan sehari-hari. Selain itu, wisatawan lokal merupakan target utama dari wisata NTT. Hal ini bertolak belakang dengan upaya pemerintah pusat untuk menarik minat wisatawan mancanegara.
\end{abstract}

Kata kunci: Pariwisata NTT, Marketing Semiotics, Brand Destination, dan Semiotika

\section{Pendahuluan}

Salah satu program utama dari pemerintahan Jokowi-JK adalah penguatan sektor pariwisata. Pemerintah memiliki target untuk menggaet 20 juta wisatawan mancanegara pada 2019 (Nugroho, 2016). Sektor pariwisata merupakan penyumbang devisa kedua terbesar di Indonesia dengan 13.586 miliar USD pada 2016, sementara di peringkat pertama datang dari industri kelapa sawit dengan 15.965 miliar USD (Rappler, 2017). 


\section{National Conference of Creative Industry: \\ Sustainable Tourism Industry for Economic Development}

Universitas Bunda Mulia, Jakarta, 5-6 September 2018

ISSN No: 2622-7436

Nusa Tenggara Timur (NTT) merupakan salah satu provinsi di Indonesia yang memiliki delapan keajaiban alam atau biasa disebut Eight Wonders (Pemerintah Daerah Provinsi NTT, 2012), yakni Taman Nasional Komodo di mana hewan langka tersebut dapat ditemui, Pink Beach di Pulau Padar, Pulau Riung, Danau Tiga Warna di kawasan Gunung Kelimutu, Taman Laut Maumere, Pantai Nihiwatu, wisata bawah laut di Pulau Alor, dan tempat selancar di Pulau Nemberalla. Tidak hanya itu, kain tenun juga menjadi salah satu faktor yang dapat menarik minat wisatawan karena termasuk sebagai warisan budaya Indonesia (Indra, 2017).

Meski memiliki modal pariwisata yang baik, hal tersebut tidak berbanding lurus dengan banyaknya wisatawan yang berkunjung. Jumlah wisatawan mancanegara yang berkunjung ke NTT hanya 112.433 orang pada 2016 dan angka itu termasuk peningkatan 20 persen dari tahun sebelumnya (Priherdityo, 2017). Dengan demikian, NTT baru menyumbang wisatawan mancanegara sebesar 0,5 persen dari total target yang diberikan pemerintah.

Pemerintah Daerah NTT melalui dinas pariwisatanya memiliki sebuah website dengan alamat www.dispar.nttprov.go.id yang juga bertautan dengan website berakronim NTT, yakniwww.newtourismterritory.com. Destinasi pariwisata diharuskan memiliki situs resmi yang dikelola pemerintah dengan tujuan memberikan informasi kepada calon pengunjungnya (Yoo and Kim, 2013; Kiralova and Pavliceka, 2014). Sektor pariwisata merupakan sebuah industri yang menitikberatkan pada arus informasinya. Menurut Lopez et al (2011), sebelum dan pada saat mengunjungi tempat wisata, turis mengakses internet dan mengunjungi situs resmi untuk mencari informasi, membagikan serta membandingkan pengalaman yang mereka dapatkan.

Dengan demikian, situs pariwisata harus memberikan kesan pertama yang menarik, informatif, dan mudah diingat calon wisatawan. Sebuah destinasi pariwisata harus tampil berbeda dari destinasi serupa lainnya agar mampu meningkatkan minat wisatawan mancanegara. Tampilan yang berbeda dapat ditunjukkan dengan memberikan konten-konten yang sudah disesuaikan pada target pasar. Hal ini mengingat keberadaan internet meningkatkan persaingan antar sesama destinasi pariwisata lainnya untuk menarik perhatian wisatawan.

Di saat yang bersamaan, suguhan situs pariwisata resmi yang dikelola oleh Pemerintah Daerah NTT, baik tampilan dan informasinya, belum dilakukan dengan baik. Bahkan, Kasim et al (2017) menilai konten promosi pariwisata di NTT masih perlu dibenahi agar bisa lebih lagi menarik perhatian wisatawan. Namun, sebelum penentuan konten, diperlukan perumusan merek destinasi wisata atau brand destination di NTT yang tepat. Menurut Oswald (2012), merek sangat penting keberadaannya untuk menentukan nilainilai simbolik di mana nilai tersebut juga menjadi pembeda utama dari competitor. Eksistensi merek ini juga bentuk komunikasi pertama yang dapat disampaikan pada publik.

\section{Rumusan Masalah}

Berangkat dari hal tersebut, peneliti ingin membedah apa merek destinasi pariwisata yang ditonjolkan oleh Pemerintah Daerah Provinsi NTT dalam situs resmi yang dikelola oleh dinas pariwisatanya.

\section{Tujuan Penelitian}

Dalam penelitian ini, diharapkan dapat diketahui merek destinasi wisata di wilayah yang memiliki delapan keajaiban alam. Pemahaman akan merek pariwisata suatu destinasi 
yang baik diharapkan dapat membantu penyusunan konten-konten pemasaran pariwisata yang tidak lagi acak, melainkan dapat menguatkan nilai jual dari merek tersebut. Sementara, secara keilmuan, penelitian ini diharapkan pula dapat menjadi referensi untuk topik terkait, maupun memberikan pengetahuan kepada pembacanya. 


\section{National Conference of Creative Industry: \\ Sustainable Tourism Industry for Economic Development}

Universitas Bunda Mulia, Jakarta, 5-6 September 2018

ISSN No: 2622-7436

\section{Tinjauan Pustaka}

\section{Pariwisata}

Undang-Undang Nomor 10 Tahun 2009 tentang Kepariwisataan, menjelaskan bahwa pariwisata adalah berbagai macam kegiatan wisata dan didukung berbagai fasilitas serta layanan yang disediakan oleh masyarakat, pengusaha, pemerintah, dan pemerintah daerah. Kasim et al (2017) mengatakan pariwisata sebagai sebuah perjalanan yang dilakukan oleh manusia dalam rentang waktu tidak lebih dari satu tahun di luar rutinitas sehari-harinya.

Sementara, Cahyadi et al (2009) menguraikan terdapat dua jenis pariwisata. Pertama, pariwisata yang bersifat massal dengan tujuan utama untuk memenuhi aspek kesenangan. Kedua, pariwisata minat khusus yang bertujuan untuk mendapatkan sebuah pengalaman maupun pengetahuan dari destinasi yang dikunjungi. Baik kedua jenis tersebut, sekembalinya individu dari sebuah destinasi wisata akan mendapatkan kenangan untuk dikenang.

Selain itu, manusia yang ingin berwisata pasti memikirkan secara matang dalam menentukan destinasi yang akan dikunjungi. Oleh karena itu, salah satu aspek utama dalam pariwisata adalah perencanaan atau sebuah aktivitas aktif dalam mencari tahu informasi terkait tempat-tempat wisata.

\section{Komunikasi Pemasaran di Pariwisata}

Komunikasi pemasaran adalah segala aktivitas yang dilakukan oleh sebuah organisasi, perusahaan, atau individu agar konsumen mengetahui barang maupun jasa yang ditawarkan (Mulholland dan Cachon, 2004). Salah satu cara untuk memasarkan ialah dengan memberikan informasi.

Penyediaan informasi mutlak dilakukan untuk memasarkan suatu destinasi wisata. Hal ini untuk menghindari pengalaman buruk yang akan dialami wisatawan ketika menikmati liburan. Sebab, menurut Mulholland dan Cachon (2004) tidak semua wisatawan memiliki kemampuan finansial yang sama dalam menentukan destinasi wisata mana yang akan dikunjungi.

Melalui komunikasi pemasaran yang baik, wisatawan pun dapat mengetahui keistimewaan suatu tempat wisata dan produk lainnya yang ditawarkan. Namun, menurut Stefko et al (2014), penyediaan informasi saja tidak cukup. Mereka mengatakan diperlukan sebuah strategi komunikasi pemasaran khusus yang mampu memotivasi wisatawan untuk mendatangi satu lokasi wisata tertentu dibanding lokasi lainnya.

Medium untuk penyampaian pesan menjadi elemen penting dalam strategi tersebut. Dewasa ini, mayoritas pemasaran dilaksanakan secara online. Gorlevskaya (2016) menegaskan situs resmi atau web-site merupakan garis awal dalam komunikasi pemasaran secara online, termasuk di dalamnya untuk memasarkan sebuah destinasi wisata. Penggunaan situs termasuk efektif karena dari segi biaya termasuk relatif murah dan mampu memicu pembicaraan atas topik tersebut sehingga mengakibatkan pemasaran dari mulut ke mulut (Stefko et al, 2014). Jangkauan kepada target pasar pun lebih luas, karena segalanya dapat diakses selama memiliki internet (Mulholland dan Cachon, 2004). Sebelum era web-site, komunikasi pemasaran pariwisata dilakukan dengan cara tradisional yang menyita waktu dan tenaga (Gorlevskaya, 2016), misalnya seperti pemasaran mulut ke mulut dari agen wisata ke target pasar, serta pembagian brosur. 


\section{National Conference of Creative Industry: \\ Sustainable Tourism Industry for Economic Development}

Universitas Bunda Mulia, Jakarta, 5-6 September 2018

ISSN No: 2622-7436

Berdasarkan penelitian yang dilakukan Stefko et al (2014, hlm. 429), komunikasi pemasaran di sektor pariwisata memerlukan pesan-pesan yang dapat meningkatkan kesadaran (awareness) wisatawan, penguatan imej destinasi wisata, menargetkan pada target pasar yang spesifik, serta membuat publisitas di ranah global demi menarik minat wisatawan mancanegara. Sementara itu, Gorlevskaya (2016) juga menganjurkan konten-konten wisata harus diperbaharui secara berkala, misal tiap jam atau tiap hari, karena lingkungan online yang kompetitif. Penyediaan konten tersebut juga mampu menciptakan reputasi positif serta membangun dan menjaga relasi dengan target wisatawan.

Tidak hanya itu, Stancioiu et al (2013) menambahkan pentingnya menciptakan sebuah merek (brand) dalam komunikasi pemasaran di ranah pariwisata. Merek sebuah destinasi wisata akan menjadi elemen utama yang berkesan bagi wisatawan. Merek tersebut juga harus dikonstruksi dengan pesan maupun konten kreatif yang selaras. Tanpa keselarasan, maka merek tersebut akan menimbulkan kesan yang kurang di benak wisatawan.

\section{Merek Destinasi Wisata (Destination BrandI)}

Penggunaan merek destinasi wisata atau destination brand kian popular diterapkan karena tiap destinasi wisata memiliki nama dan keunikannya sendiri. Tanpa merek tertentu, wisatawan seakan dibombardir dengan informasi-informasi monoton tentang suatu wilayah dan alasan mengapa mereka harus mengunjungi tempat tersebut. Mayoritas informasi tersebut menitikberatkan pada pesan-pesan berupa betapa ramahnya warga lokal, pemandangan alam yang asri dan indah, dan atau fasilitas yang baik (Semone dan Kozak, 2012).

Konsep merek destinasi wisata ini pertama kali diperkenalkan oleh Ritchie dan Ritchie (1998). Mereka menjelaskan merek destinasi wisata sebagai sebuah nama, simbol, logo, kata-kata, atau grafis yang menunjukkan ciri khas dan membedakan sebuah tempat wisata, yang memberi sebuah 'janji' akan pengalaman berkesan yang didapat dari sebuah destinasi, serta menguatkan kenangan indah akan destinasi wisata itu. (Ritchie dan Ritchie, 1998, hlm. 103).

Semone dan Kozak (2012) mengatakan keberhasilan merek destinasi wisata ditentukan oleh seberapa dalam dan matang konsep yang dibangun. Selain itu, keselarasan demi penguatan merek tersebut juga harus dalam satu payung besar yang sama. Hal ini berarti sebuah merek harus didukung oleh 'logo, slogan, visi-misi, dan nilai-nilai yang saling terkait dan saling menguatkan' (Semone dan Kozak, 2012, hlm. 598).

Menurut Stancioiu (2011), antar destinasi wisata tidak akan bersaing dalam soal harga, melainkan persaingan akan terjadi dalam level merek. Merek yang memberikan kesan dan imej positif bagi wisatawan akan mendapatkan keuntungan. Hal ini berarti proses penyusunan maupun pembuatan merek destinasi wisata yang baik juga harus memikirkan sudut pandang wisatawan sebagai konsumen. 


\section{National Conference of Creative Industry: \\ Sustainable Tourism Industry for Economic Development}

Universitas Bunda Mulia, Jakarta, 5-6 September 2018

ISSN No: 2622-7436

\section{Metodologi}

Penelitian ini merupakan penelitian kualitatif yang mengedepankan metode induktif untuk memahami suatu fenomena (Bhattacherje, 2012). Peneliti mengutamakan pendekatan interpretasi yang memunculkan ide-ide orisinil dalam mencari jawaban bagaimana pengalaman sosial terbentuk dan memiliki makna. Selain itu, penelitian kualitatif ini juga bersifat fleksibel atau tidak kaku, tapi tetap mengikuti pedomanpedoman yang berlaku.

Unit analisis dalam penelitian ini adalah web-site yang dikelola oleh Dinas Pariwisata Pemerintah Daerah NTT, yakni www.newtourismterritory.com. Situs tersebut diakses pada Senin 30 Juli 2018. Peneliti mengetahui situs tersebut dari laman utama www.dispar.nttprov.go.id, karena setiap konten yang diklik selalu terbuka di laman www.newtourismterritory.com. Peneliti hanya mendalami tanda-tanda (logo, foto-foto, dan teks) yang muncul di halaman beranda situs tersebut, untuk mengetahui merek pariwisata apa yang berusaha ditonjolkan.

Peneliti menggunakan analisis semiotika dalam studi kasus ini. Kerangka yang dipakai adalah analisis semiotika pemasaran Laura Oswald (2012). Lebih detil, peneliti akan memakai konsep consumer brandscape. Consumer brandscape sebagai proses integrasi makna-makna dalam sebuah sektor bisnis tertentu, yang menguatkan persepsi konsumen ketika melihat sebuah merek. Pariwisata termasuk dalam lahan usaha, dengan wisatawan sebagai konsumennya, sehingga konsep tersebut dapat diterapkan (Oswald 2012; Septyana, 2017).

Menurut Oswald (2012), consumer brandscape terbentuk dari sistem simbolik yang mengintegrasikan dimensi sosial, budaya, dan merek (brand). Di dalam sistem tersebut terbagi dalam beberapa dimensi, yakni kode-kode terstruktur yang membentuk kategori budaya, teritori emosi yang berkaitan dengan kategori, dan gabungan signifiers (penanda) untuk mengkomunikasikan representasi makna atau citra merek. Pemahaman akan consumer brandscape juga berguna dalam proses memahami konsep serta citra merek yang berasal dari perspektif konsumen.

Peneliti akan melihat secara komprehensif situs tersebut dengan memerhatikan lima hal yakni seleksi dan kombinasi, paradigma dan sintagma, metafora dan metonimi, makna dan rujukan, serta aspek kebahasaan. Kelima hal tersebut diambil dari kerangka berpikir Oswald (2012) yang bertujuan untuk encoding (proses mengubah pikiran atau komunikasi ke dalam pesan) dan decoding (proses membaca dan memahami pesan) untuk memahami merek destinasi wisata seperti apa yang ingin dikomunikasikan oleh Dinas Pariwisata Pemerintah Daerah NTT. 


\section{National Conference of Creative Industry: \\ Sustainable Tourism Industry for Economic Development}

Universitas Bunda Mulia, Jakarta, 5-6 September 2018

ISSN No: 2622-7436

\section{Hasil dan Pembahasan \\ Hasil}

Berdasarkan penjelasan metodologi yang telah diurai pada bab sebelumnya, maka berikut ini adalah hasil dari analisis semiotika yang dilakukan.

A. Seleksi dan Kombinasi

Dalam halaman beranda www.newtourismterritory.com, tampilan yang muncul pertama kali ketika situs tersebut diakses adalah gambar-gambar lokasi wisata yang silih berganti tiap 15 detik. Adapun enam gambar yang muncul, yakni Pantai Paihaka, Masjid Tua Lerabaing, Air Terjun Matayangu, Danau Tana Ronjong, Gua Maria Bitauni, serta Air Terjun Oenesu. Penjelasan gambar tersebut menggunakan teks dalam Bahasa Indonesia.

Simbol wisata bahari ditunjukkan dari gambar Pantai Paihaka. Dari gambar 4. 1 di bawah, tampak sisi biru laut yang tenang dan jernih dengan pasir putih yang mengkilat. Tak jauh, juga tampak pohon-pohon rindang dengan langit cerah yang menunjukkan keasrian. Sebagai wilayah kepulauan maka tidak heran untuk menonjolkan keindahan pantai di NTT.

Gambar yang dipakai menunjukkan waktu siang hari sehingga menunjukkan warna yang cerah, dengan mayoritas nuansa biru. Warna biru yang terlihat dari unsur laut dan langit memiliki arti ketenangan serta mengandung sisi artistik yang menguatkan keindahan bahari. Sementara, warna hijau yang berasal dari pepohonan memberi efek suasana yang santai dan menyegarkan.

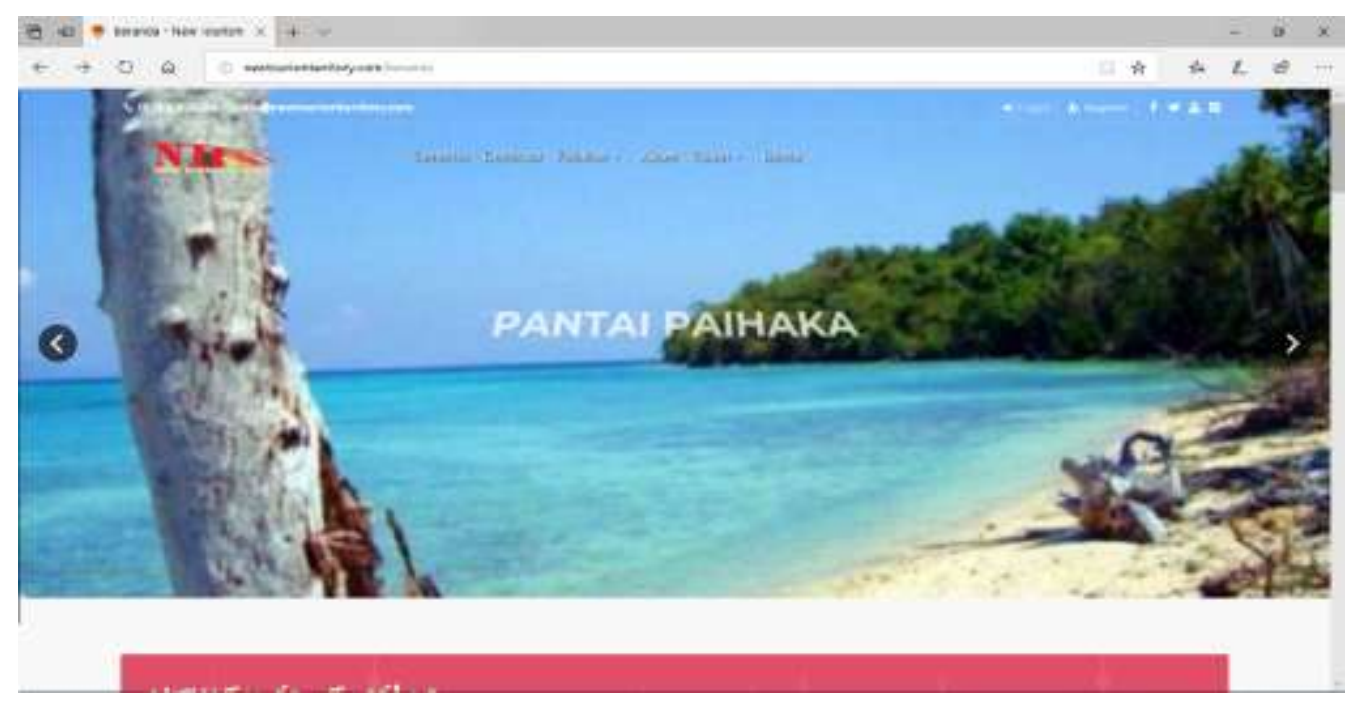

Gambar 4. 1 Simbol Wisata Bahari 


\section{National Conference of Creative Industry: \\ Sustainable Tourism Industry for Economic Development}

Universitas Bunda Mulia, Jakarta, 5-6 September 2018

ISSN No: 2622-7436

Sementara itu, simbol wisata alam disampaikan melalui tampilan gambar dari Air Terjun Matayangu, Danau Tana Ronjong, serta Air Terjun Oenesu. Daya tarik keasrian alam NTT ditonjolkan dari tiga gambar di bawah ini. Hal ini disebabkan kencenderungan perkembangan pariwisata mulai mengarah pada wisata alam. Mayoritas masyarakat modern menetap di perkotaan yang notabene jauh dari lingkungan alam yang asri.

Serupa dengan simbol wisata bahari, ketiganya menampilkan gambar yang diambil di pagi atau siang hari, bukan malam hari, sehingga menunjukkan nuansa yang cerah serta sejuk. Kecerahan terlihat dari warna-warni yang ditunjukkan, sementara kesejukkan berasal dari elemen air yang ada di dalam gambar-gambar.
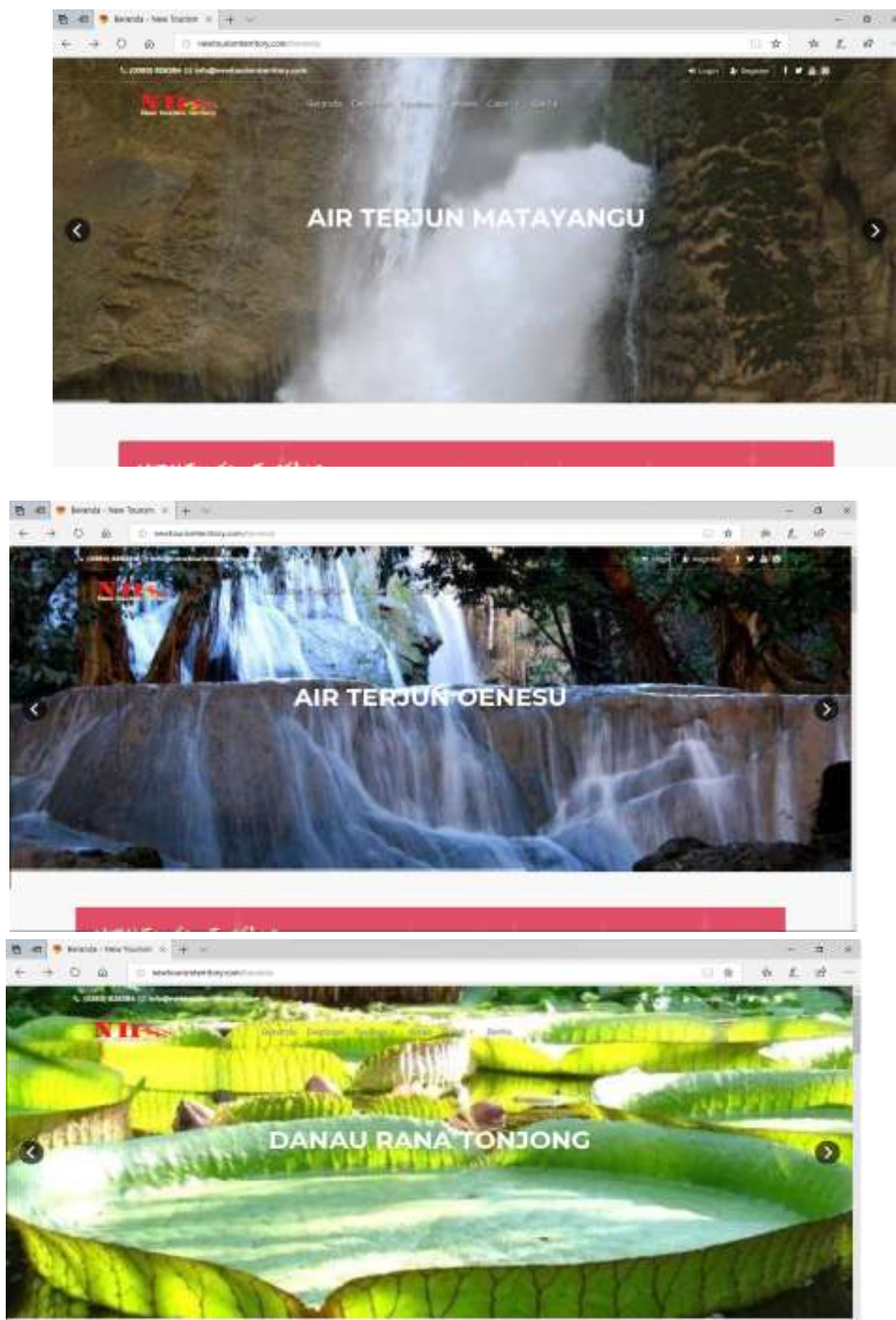
Lebih lanjut, simbol wisata religi terlihat dari gambar Masjid Tua Lerabaing dan Gua Maria Bitauni. Dari dua foto ini, Dinas Pariwisata Pemerintah Daerah NTT seakan berusaha menunjukkan adanya keberagaman agama yang mampu menjadi daya tarik.

Kedua destinasi wisata religi yang ditampilkan mewakili kelompok agama Islam (Masjid Tua Lerabaing dan Katolik (Goa Maria Bitauni). Bangunan masjid pun berbeda dengan masjid pada umumnya, karena dibangun sesuai dengan bentuk kultur dan adat setempat. Sementara itu, Goa Maria Bitauni menampilkan sisi keindahan goa yang terbentuk alami dengan patung Bunda Maria.
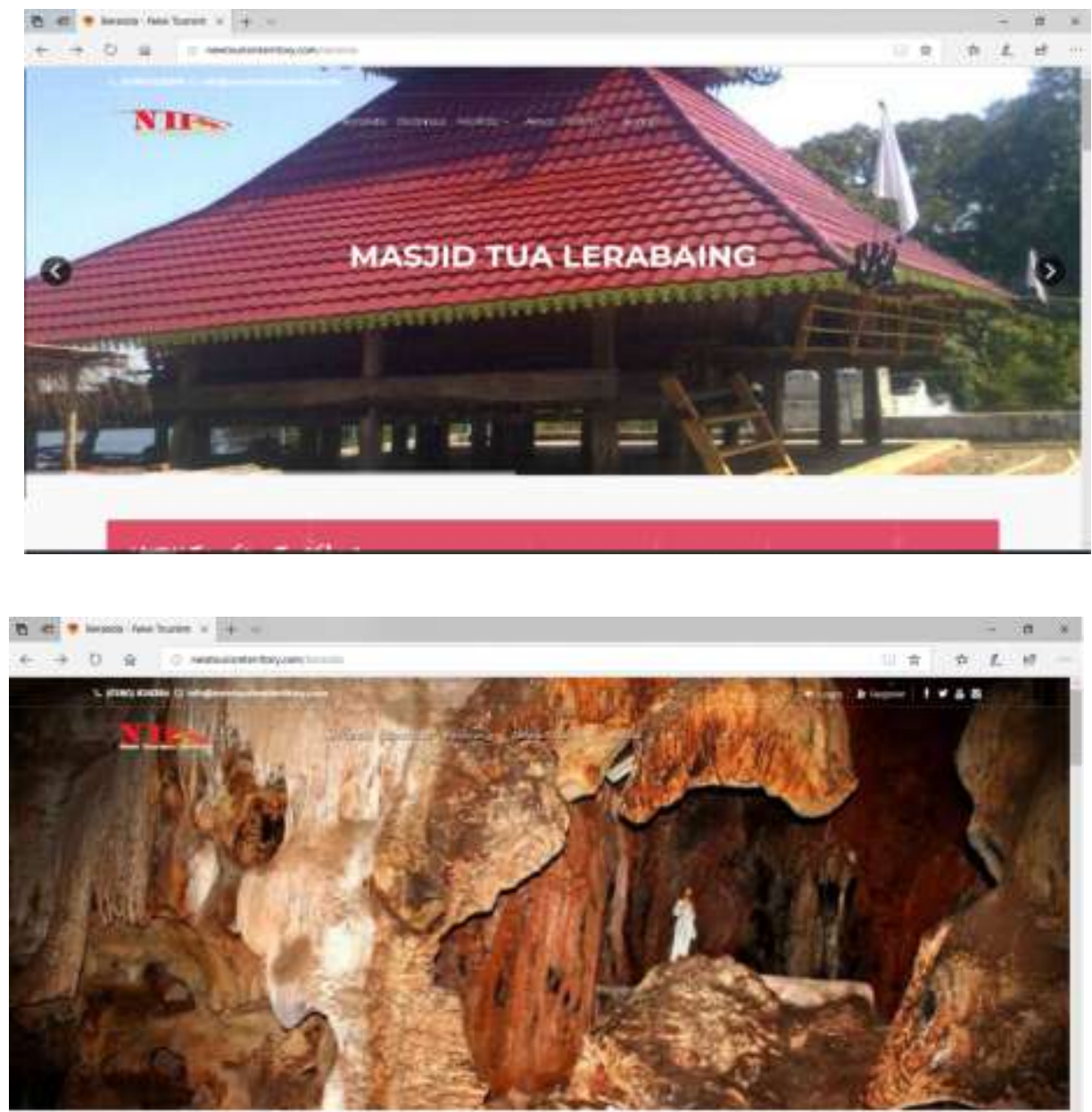


\section{Gambar 4.3 Simbol Wisata Religi}

Selain itu, situs ini juga menampilkan pula hewan purba dan langka yang hanya hidup di NTT, yakni komodo. Penampakan hewan ini juga senada dengan logo yang digunakan oleh website ini. Logo ini terletak di bagian atas kiri, dengan mayoritas berwarna merah dan sedikit warna kuning untuk teksnya. Logo tersebut juga selalu konsisten muncul, walau gambar lainnya silih berganti. Warna merah membentuk tulisan NTT dan terdapat bentuk komodo setelah tulisan tersebut. Sementara, teks yang berwarna kuning bertuliskan New Tourism Territory. Sayangnya, ukuran dari logo ini sekitar $1 \times 2 \mathrm{~cm}$. Dalam logo tersebut, Dinas Pariwisata Pemerintah Daerah NTT ingin menampilkan hewan purba yang langka, yakni komodo.

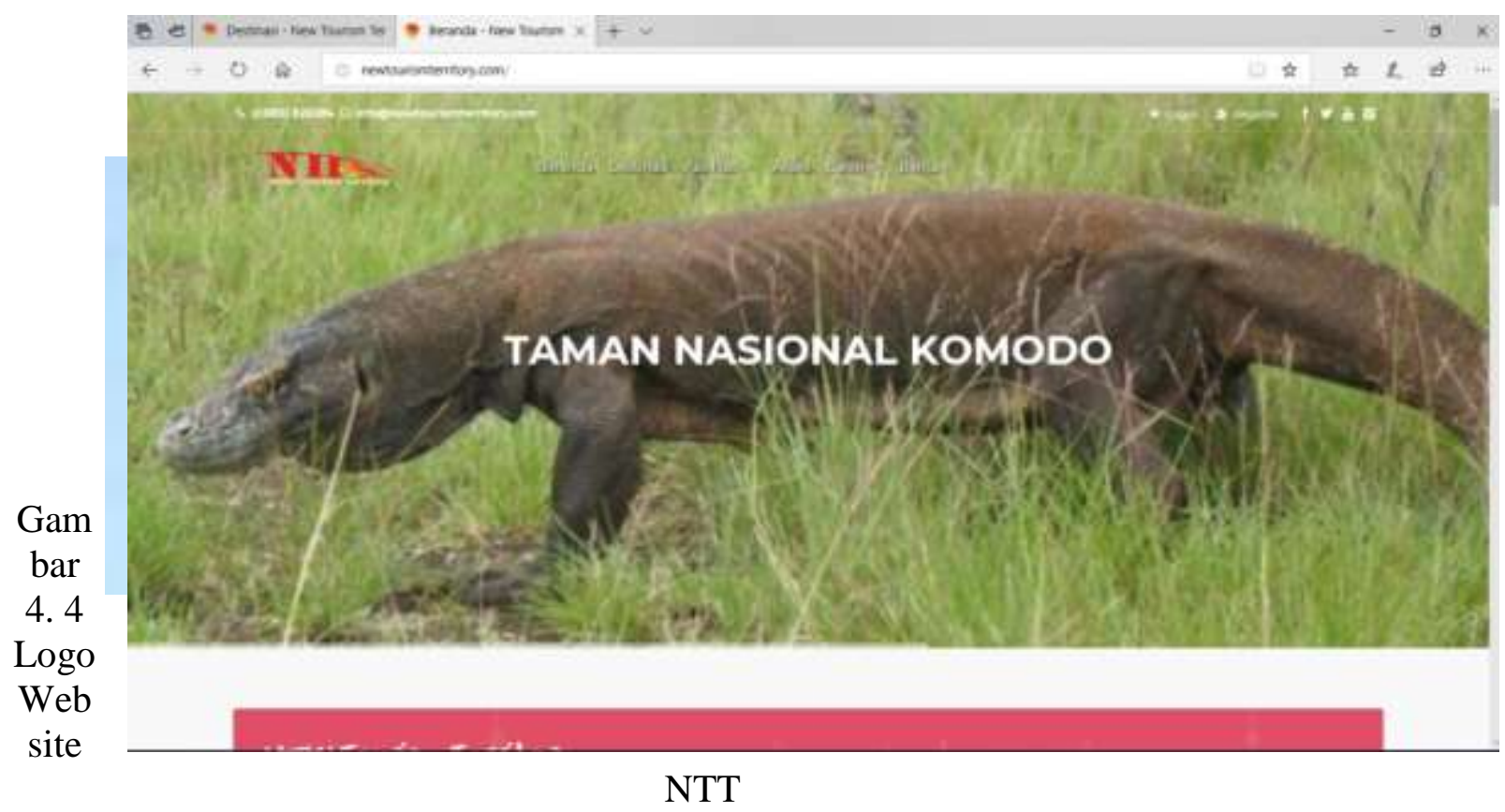

Dengan demikian, dapat ditarik benang merah bahwa konsep utama dari tampilan gambar-gambar di halaman beranda www.newtourismterritory.com berfokus pada wisata alam dan wisata religi. Dinas Pariwisata Pemerintah Daerah NTT berusaha mengajak wisatawan untuk menikmati keindahan alam, termasuk di dalamnya pantai, laut, danau, maupun hewan langka komodo, serta pengalaman spiritual yang berpadu dengan budaya lokal atau alam.

B. Paradigma dan Sintagma

Paradigma merupakan serangkaian tanda yang bisa membantu untuk terciptanya sebuah makna atas dasar kesamaan. Berdasarkan halaman beranda di www.newtourismterritory.com, maka konsep wisata alam dan wisata religi merupakan paradigm yang muncul dari situs tersebut. 


\section{National Conference of Creative Industry: \\ Sustainable Tourism Industry for Economic Development}

Universitas Bunda Mulia, Jakarta, 5-6 September 2018

ISSN No: 2622-7436

Sementara, sintagma dapat diartikan sebagai intrepretasi pesan yang berasal dari tanda-tanda yang digunakan. Dengan demikian, konsep-konsep yang muncul dari paradigma website resmi dinas pariwisata NTT dapat dipadankan sebagai tempat wisata yang membawa ketentraman jasmani dan rohani, membawa kedamaian, dan bebas stress.

Nusa Tenggara Timur memang salah satu wilayah Indonesia yang masih asri dan keindahan alamnya yang natural. Potensi alam tersebut yang berusaha ditawarkan oleh dinas pariwisata daerah itu kepada wisatawan. Hal ini ditunjukkan melalui nuansa alam yang lapang dan juga bebas, seperti di pantai yang bersebelahan dengan laut maupun langit biru yang didukung pula dengan cuaca cerah.

C. Metafora dan Metonimi

Sebuah merek dapat diklasifikasikan dalam dua hal yaitu metafora dan metomini. Metafora merupakan penggantian suatu istilah dengan istilah yang sejenis atau serupa, sedangkan metonimi merujuk pada subtitusi satu istilah dengan istilah yang relevan dan berkesinambungan (contiguitiy).

Metafora yang tampak dari simbol wisata alam dan wisata religi ini dapat digantikan dengan destinasi wisata yang nyaman bagi jasmani maupun rohani, dan tempat yang mampu menghilangkan stress. Ide metafora tersebut berdasarkan pada tampilan gambar-gambar yang muncul maupun logo dalam website pariwisata NTT ini menitikberatkan pada pemandangan alam yang melibatkan air laut dan juga air terjun, serta kearifan lokal.

Sementara, metonimi yang dapat dikaitkan dari simbol wisata alam dan wisata religi adalah kelompok wisatawan yang sehari-hari bertempat tinggal di area perkotaan. Lebih lanjut, kelompok wisatawan ini juga berasal dari individuindividu yang beragama Islam atau Katolik atau mereka yang menyukai lokasi religi. Suasana perkotaan yang sesak dengan gedung pencakar langit ditambah minimnya keindahan alam membuat tawaran untuk berlibur ke daerah yang masih asri menjadi relevan.

D. Makna dan Rujukan

Dalam situs resmi Dinas Pariwisata Pemerintah Daerah NTT, terlihat jelas bahwa makna yang diupayakan adalah menarik minat wisatawan untuk menikmati keindahan dan keasrian alam mereka. Begitu pula dengan menonjolkan keberadaan komodo, hewan purba dan langka yang diakui oleh dunia sebagai warisan budaya. Tidak lupa, destinasi religi yang terpadu dengan budaya lokal. Hal-hal tersebut tertuang dalam rencana besar pengembangan pariwisata NTT (Pemerintah Daerah NTT, 2012). Pengakuan keindahan alam pun sudah diakui dunia sebagai destinasi yang memiliki eight wonders.

Warna dalam gambar-gambar yang ditampilkan bersifat cerah, menandakan keceriaan. Wisatawan diarahkan untuk mendapatkan pengalaman liburan yang menyenangkan dengan cara menikmati keindahan alam. Lebih lanjut, mayoritas 
warna biru dan hijau yang terpancar, memiliki makna ketenangan dan menghilangkan stress.

Sementara itu, rujukan dapat terlihat dari tag-line yang berada di bawah logo NTT dan gambar komodo, yakni new tourism territory. Dinas Pariwisata NTT seakan ingin menunjukkan wilayah mereka sebagai destinasi wisata baru yang masih jarang dikunjungi wisatawan. Hal ini juga menandakan pula NTT dapat menjadi pilihan alternatif bagi individu yang rutin berwisata dan ingin mencari destinasi baru.

E. Aspek Kebahasaan

Terdapat dua bahasa utama yang digunakan dalam mengisi konten di situs www.newtourismterritory.com, yaitu Bahasa Indonesia dan Bahasa Inggris. Namun, mayoritas bahasa yang dipakai adalah Bahasa Indonesia. Hal tersebut terlihat dari kata-kata yang menghiasi kanal-kanal situs sampai dengan penjelasan akan suatu destinasi wisata.

Pemakaian Bahasa Inggris hanya dipakai dalam alamat website dan logo serta tagline saja. Selain itu, tidak ada pula fitur untuk memilih bahasa di luar Bahasa Indonesia.

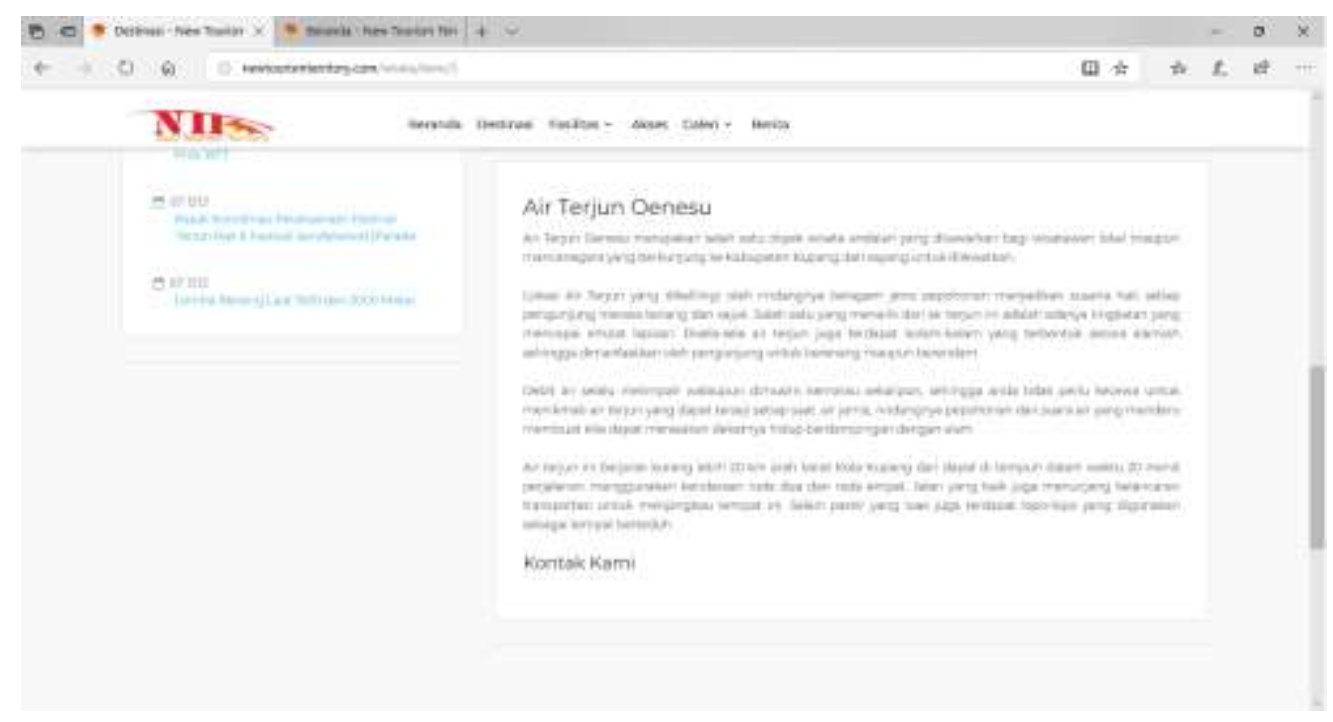




\section{National Conference of Creative Industry: \\ Sustainable Tourism Industry for Economic Development}

Universitas Bunda Mulia, Jakarta, 5-6 September 2018

ISSN No: 2622-7436

Gambar 4. 5 Konten dengan Bahasa Indonesia

\section{Pembahasan}

Nusa Tenggara Timur (NTT) memiliki modal besar untuk menarik minat wisatawan baik lokal maupun mancanegara. Alasannya, daerah tersebut mempunyai potensi alam yang indah dan juga kearifan budaya lokal yang orisinil. Simbol-simbol itulah yang berusaha ditampilkan dalam situs www.newtourismterritory.com. Simbol-simbol tersebut melebur menjadi merek destinasi wisata tertentu yang kemudian membangun sebuah imej serta meninggalkan kesan kuat bagi wisatawan (Blain et al, 2005). Merujuk pada konsep consumer brandscape oleh Oswald (2012), pada tahapan Seleksi dan Kombinasi, dinas pariwisata NTT berusaha mengemas merek destinasi wisata NTT menjadi dua ide besar, yaitu wisata alam serta wisata religi.

Bila ditelaah lebih mendalam, konsep wisata alam merupakan wisata yang menikmati fenomena keindahan alam yang bebas dari rekayasa manusia. Chiu et al (2016) menjelaskan tiga elemen penting yang harus hadir agar sebuah wisata termasuk dalam kategori wisata alam, yakni terdapat dampak ekonomi dan sosial pada daerah wisata itu, pengaruh positif terhadap konservasi destinasi alamnya, dan pengembangan komunitas lokal di daerah wisata alam itu. Hal tersebut tampak sejalan dengan apa yang ditampilkan dalam website resmi Dinas Pariwisata NTT dengan menunjukkan keindahan pantai, danau, air terjun, serta hewan langka komodo, melalui tampilan gambar yang berganti tiap 16 detik di halaman beranda website mereka. Sayangnya, gambar destinasi wisata yang ditampilkan bukanlah destinasi yang masuk dalam daftar eight wonders, hanya ada satu dari delapan keajaiban alam yang diperlihatkan.Adapun eight wonders itu adalah Taman Nasional Komodo, Pink Beach di Pulau Padar, Pulau Riung, Danau Tiga Warna di kawasan Gunung Kelimutu, Taman Laut Maumere, Pantai Nihiwatu, wisata bawah laut di Pulau Alor, dan tempat selancar di Pulau Nemberalla.

Sebaiknya, gambar-gambar yang ditampilkan, terutama di halaman beranda website, adalah destinasi utama NTT yang sudah mendapat pengakuan dan masuk dalam master plan pengembangan wisata 2013-2023 (Pemerintah Daerah NTT, 2012). Sebab, website merupakan ujung tombak dalam memasarkan suatu destinasi wisata (Gorlevskaya, 2016). Semakin sering suatu destinasi wisata muncul, makin sering pula terjadi integrasi pada benak individu yang melihat simbol-simbol wisata, sehingga berujung pada peningkatan probabilitas individu untuk mempertimbangkan pergi ke daerah itu.

Sementara, wisata religi ialah wisata yang dilakukan oleh turis atau wisatawan yang sehari-harinya mengamalkan sebuah praktik kepercayaan tertentu. Menurut Terzidou et al (2018), karakteristikdalam wisata religi terletak pada sisi wisatawan dalam pencarian jati diri dan spiritiual, serta di saat bersamaan mengapresiasi kesakralan destinasi tersebut. Tampilan gambar-gambar untuk mewakili wisata religi sudah tepat karena menunjukkan Masjid Tua dan Goa Maria.

Lebih lanjut, dalam tahap Paradigma dan Sintagma, simbol-simbol yang terdapat di situs berusaha menyampaikan pada wisatawan, bahwa destinasi wisata NTT merupakan tempat yang baik bagi jasmani dan rohani karena bersentuhan dengan alam yang indah. Meski demikian, pesan ini tampak kurang karena dalam tiap gambar yang ditampilkan 


\section{National Conference of Creative Industry: \\ Sustainable Tourism Industry for Economic Development}

Universitas Bunda Mulia, Jakarta, 5-6 September 2018

ISSN No: 2622-7436

tidak menyisipkan sama sekali unsur manusia. Dinas Pariwisata NTT dapat mempertimbangkan untuk melibatkan unsur manusia di dalam gambar-gambar destinasi wisata yang ingin mereka tonjolkan. Hal ini untuk memberikan gambaran pada calon wisatawan atas pengalaman menyenangkan seperti apa yang menanti, bila mereka memutuskan datang ke NTT (Mulholland dan Cachon, 2004). Sebab, Blain et al (2005) menuturkan pentingnya gambar yang yang dapat berinteraksi dengan emosi wisatawan. Kehadiran unsur manusia dalam suatu gambar, dapat memberi gambaran wisatawan berada di posisi yang sama seperti di gambar.

Kemudian, pada tahap metafora dan metonimi, juga mengungkapkan NTT sebagai destinasi yang tepat untuk kesehatan jasmani dan rohani, serta wisata yang menghilangkan stress. Jika melihat dari sisi metonimi atau keberlanjutannya, dapat dilihat destinasi wilayah ini ditujukan pada wisatawan yang kesehariannya menetap di perkotaan. Selanjutnya, dalam makna dan rujukan, pariwisata NTT dikemas sebagai sebuah destinasi baru atau alternatif bagi mereka yang ingin meninggalkan sejenak rutinitasnya di perkotaan. Dalam tahap-tahap tersebut, terbentuk sebuah identitas yang memisahkan destinasi wisata NTT dengan destinasi wisata lainnya. Kashif et al (2015) mengatakan asosiasi-asosiasi terhadap sebuah merek destinasi wisata yang memiliki keselarasan ide akan menghasilan brand equity atau seberapa kuat suatu merek di benak konsumen atau wisatawan. Ujung dari brand equity ini merupakan loyalitas merek atau brand loyalty (Gomez et al, 2015).

Terakhir, dari aspek kebahasaan, agak disayangkan website ini tidak menggunakan Bahasa Inggris sebagai bahasa utama untuk mengisi konten maupun caption di tiap gambar-gambar yang ditampilkan. Dengan demikian, antara wisatawan mancanegara potensial dan destinasi wisata NTT terdapat sebuah tembok pembatas berupa problematika bahasa. Al-Saadi (2015) menuturkan Bahasa Inggris termasuk bahasa internasional utama yang umumnya dipakai untuk memasarkan pariwisata. Lebih lanjut, Bahasa Inggris merupakan sarana komunikasi yang vital dalam memasarkan sebuah destinasi wisata (Bobanovic dan Grzinic, 2011). Penggunaan Bahasa Inggris ini pun harus diwujudkan tidak hanya dalam komunikasi lisan, melainkan juga secara tulisan. Temuan dari aspek kebahasaan ini juga menjadi jawaban mengapa pariwisata NTT yang memiliki modal dan potensi alam luar biasa hanya mampu menarik sedikit wisatawan mancanegara. Hal ini menyiratkan upaya Pemda NTT bertolak belakang dari rencana yang digariskan pemerintah pusat, yaitu target 20 juta wisatawan mancanegara.

\section{Simpulan}

Dalam halaman beranda website www.newtourismterritory.com, Dinas Pariwisata NTT berusaha untuk mengkomunikasi potensi wisata alam dan wisata religi sebagai merek destinasi wilayah tersebut. Namun, simbol-simbol berupa gambar yang tampil di halaman beranda tidak menampilkan destinasi wisata utama yang masuk dalam eight wonders.

Lebih lanjut, situs wisata NTT ini juga berusaha mengkomunikasikan pesan bahwa, NTT merupakan destinasi wisata yang menyehatkan jasmani dan rohani. Alam yang indah dan asri dapat membantu menghilangkan ketegangan atau stress sehingga baik bagi jasmani wisatawan. Sementara, wisata religi juga dianggap mampu meningkatkan kedekatan spiritual wisatawan ke Tuhan YME.

Dari analisa semiotika diketahui pula bahwa target pasar adalah individu-individu yang sehari-hari hidup di perkotaan. Sebab, destinasi wisata yang ditonjolkan dikemas sebagai lokasi alternatif bagi target pasar untuk keluar sejenak dari rutinitasnya. 
Selain itu, website ini kurang memerhatikan wisatawan mancanegara karena kontenkonten maupun caption menggunakan Bahasa Indonesia. Dengan demikian, informasi yang berada di situs ini terbatas pada wisatawan lokal saja. Potensi alam yang luar biasa menjadi sia-sia.

\section{Saran dan Limitasi Penelitian}

Peneliti menilai ada tiga hal yang perlu dibenahi dalam pengelolaan situs www.newtourismterritory.com dalam memasarkan destinasi wisata NTT. Pertama, perlunya menampilkan simbol-simbol gambar destinasi wisata yang termasuk dalam eight wonders sehingga meninggalkan kesan yang kuat bagi wisatawan. Kedua, menambahkan simbol manusia dalam gambar-gambar yang ditampilkan, supaya wisatawan bisa lebih mudah membayangkan dirinya berada di destinasi wisata tersebut. Ketiga, situs ini perlu menggunakan dua bahasa, Bahasa Indonesia dan Bahasa Inggris, secara seimbang dalam penyampaian kontennya. Bahasa Indonesia untuk memfasilitasi wisatawan lokal, sementara Bahasa Inggris untuk menjangkau wisatawan mancanegara. Penelitian ini bukanlah tanpa cacat karena berusaha memahami merek destinasi wisata NTT dalam satu platform komunikasi saja. Dengan demikian, perlu dilakukan penelitian lanjutan untuk melihat merek destinasi wisata dalam multi platform dengan tujuan mengetahui apakah terdapat keselarasan merek

\section{Biodata}

Silvanus Alvin merupakan Dosen Ilmu Komunikasi di Universitas Bunda Mulia, Jakarta. Gelar sarjana (S1) dengan konsentrasi keilmuan Jurnalistik, didapat dari Universitas Multimedia Nusantara, Gading Serpong, pada 2013. Dalam periode 20122016, Alvin meniti karir sebagai wartawan media online di Liputan6.com. Jabatan terakhirnya adalah wartawan istana yang sehari-hari meliput Presiden Joko Widodo dan Wakil Presiden Jusuf Kalla. Selanjutnya, Alvin mendapat beasiswa LPDP pada medio 2016, lantas melanjutkan studi di University of Leicester, Inggris. Bidang keilmuan yang dipelajar secara komprehensif adalah Media dan Public Relations. Gelar Master of Arts diraih pada 2017. 


\section{National Conference of Creative Industry: \\ Sustainable Tourism Industry for Economic Development}

Universitas Bunda Mulia, Jakarta, 5-6 September 2018

ISSN No: 2622-7436

\section{Daftar Pustaka}

Al-Saadi, N. (2015) Importance of English Language in the Development of Tourism Management, Academic Journal of Accounting and Economic Researches, 4, pp. 33-45. Bhattacherjee, A. (2012). Social Science Research: Principles, Methods, and Practices. Tampa: University of South Florida.

Bobanovic, M. dan Grzinic, J. (2011) The importance of English Language skills in the tourism sector: A comparative study of students/employees perceptions in Croatia, Journal of Tourism, Culture and Territorial Development, 4, pp. 10-23.

Blain, C. et al (2005) Destination Branding: Insights and Practices from Destination Management Organizations, Journal of Travel Research, 43, pp. 328-338.

Cahyadi, R. et al. (2009) Pariwisata Pustaka: Masa Depan bagi Kita, Alam, dan Warisan Budaya Bersama. Jakarta: UNESCO.

Chiu, H. Y. et al. (2016) Local perception and preferences in nature tourism in Hong Kong, Tourism Management Perspectives, 20, pp. 87-97.

Gomez, M. et al. (2015) A model of tourism destination brand equity: The case of wine tourism destinations in Spain, Tourism Management, 51, pp. 210-222.

Gorlevskaya, L. (2016) Building Effective Marketing Communications in Tourism, Studia commercialia Bratislavensia, 9 (35), pp. 252-265.

Indra, R. 2017. 33 Kain Tradisional Ditetapkan Jadi Warisan Budaya. Diakses pada 28 Juli 2018, dari https://www.cnnindonesia.com/gaya-hidup/20170824194938-277237118/33-kain-tradisional-ditetapkan-jadi-warisan-budaya

Kasim, A. et al. (2017) Strategi Promosi Pariwisata Kota Kupang Melalui Pembuatan Media Katalog Wisata. Journal of Management, 4 (1), pp 71-90.

Kashif, M. et al. (2015) Brand equity of Lahore fort as a tourism destination brand, Revista de Administracao de Empresas, 55(4), pp. 432-443.

Kiralova, A. and Pavliceka, A. (2014) Development of Social Media Strategies in Tourism Destination. Procedia - Social and Behavioral Sciences, 175, pp. 358-366.

Lopez, E. P. et al. (2011) Intentions to use social media in organizing and taking vacation trips. Computers in Human Behavior, 27, pp 640-654.

Mulholland, R. dan Cachon, J. C. (2004) Online Marketing Communication in the Tourism Industry: An Explanatory Study of Website Effectiveness among Tourist Lodge Operators in Northern Ontario, Journal of Small Business and Entrepreneurship, 17 (3), pp. 175-186.

Nugroho, B. 2016. Jokowi: Target Saya ke Menpar 20 Juta Wisatawan, Kalau Tak Tercapai? Dicopot. Diakses pada 28 Juli 2018, dari https://news.detik.com/berita/d3360087/jokowi-target-saya-ke-menpar-20-juta-wisatawan-kalau-tak-tercapai-dicopot Oswald, L. R. (2012) Marketing Semiotics: Signs, Strategies, and Brand Values $\left(1^{\text {st }}\right.$ ed). New York: Oxford University Press.

Pemerintah Daerah Provinsi NTT (2012) Master Plan Pariwisata NTT 2013-2023. Kupang: Pemerintah Daerah Provinsi NTT.

Priherdityo, E. 2017. NTT Yakin Kunjungan Wisatawan Naik 30 Persen di 2017. Diakses pada 28 Juli 2018, dari https://www.cnnindonesia.com/gayahidup/20170123122504-269-188243/ntt-yakin-kunjungan-wisatawan-naik-30-persendi-2017

Rappler. 2017. Tiga Tahun Jokowi-Jk: 5 Pencapaian di sektor pariwisata. Diakses pada 28 Juli 2018, dari https://www.rappler.com/indonesia/berita/nasional/185679-tigatahun-jokowi-jk-5-pencapaian-pariwisata 


\section{National Conference of Creative Industry: \\ Sustainable Tourism Industry for Economic Development}

Universitas Bunda Mulia, Jakarta, 5-6 September 2018

ISSN No: 2622-7436

Ritchie, J. R. dan Ritchie, R. J. (1998) The Branding of Tourism Destinations: Past Achievements and Future Challenges, Proceedings of the 1998 Annual Congress of the International Association of Scientific Experts in Tourism, Destination Marketing: Scopes and Limitations, edited by Peter Keller, Marrakech, Morroco: International Association of Scientific Experts in Tourism, pp. 89-116.

Semone, P. dan Kozak, M. (2012) Towards a Mekong Tourism Brand, Asia Pacific Journal of Tourism Research, 17 (6), pp. 595-614.

Septyana, V. (2017) Fenomena Meikarta sebagai Simbol Modernitas: Studi Semiotika Pemasaran Oswald dalam Iklan Kota Meikarta. Universitas Bunda Mulia.

Stancioiu, A. F. et al. (2011) The Image of the Tourism Destination - a Supporting Element in the Development of the Regional Tourism Brand Study Case: Muntenia, Theoritical and Applied Economics, 18 (2), pp. 139-152.

Stancioiu, A. F. et al. (2013) Integrated marketing communication in tourism - an analysis. Case study: Muntenia and Oltenia, Theoretical and Applied Economics, 6(583), pp. 7-34.

Stefko, R. et al. (2014) Strategic Marketing Communication in Pilgrimage Tourism, Procedia - Social and Behavioral Sciences, 175, pp. 423-430.

Terzidou, M. et al. (2018) The complexities of religious tourism motivations: Sacred places, vows, and visions, Annals of Tourism Research, 70, pp. 54-65.

Yoo, K.H. and Kim, J.R. (2013) How U.S. state tourism offices use online newsrooms and social media in media relations. Public Relations Review, 39, pp. 534-541. 